present arrangements secure an integration of military and scientific effort at least as good as anything which exists in any other country. The close cooperation ensures that our resources in science and technology are fully applied to the improvement and equipment of the Services, while co-operation between operational research scientific workers and the fighting men ensures the best use of the weapons we have.

The Defence Research Policy Committee effects a proper allocation of resources between the different Services and their various projects, and in this connexion Lord Alexander paid a tribute to the work of Sir Henry Tizard. The right policy, Lord Alexander believes, is to go into immediate production in quantity when we think we have found something really good and not delay in the hopes of finding something still better. The danger lies in dispersing our effort on all kinds of interim equipment. Lord Pakenham, who expressed doubts as to whether we are making full use of our potential supply of scientific workers, said that, in his opinion, the Admiralty does not employ as many scientific men as it should; in reply, the Secretary of State for Air stated that there is no intention of reducing the number of scientific workers used by the Admiralty, but for security reasons he was unable to supply Lord Winster with the information he requested regarding development and research on guided missiles; nor did he deal with the question of political warfare and the contributions of the British Broadcasting Corporation and the British Council, which were raised by Lord Kenswood.

\section{Register of Biological Consultants}

THE Institute of Biology has recently established a Register of Biological Consultants. Subjects covered by biologists on the register include agronomy, bacteriology, biochemistry, ecology, entomology, fisheries, forensic biology, histology, microbiology, nutrition, pest control, protozoology, river pollution, and wild-life conservation. The Institute is now in a position to recommend specialist advisers in any branch of the biological sciences to those requiring their services. Inquiries should be addressed to the General Secretary, Institute of Biology, Tavistock House South, Tavistock Square, London, W.C.1.

\section{Harwell Unclassified Reports}

FIFTY-ONE unclassified scientific reports issued by the Atomic Energy Research Establishment, Harwell, are now available (London: H.M.S.O.). As the director, Sir John Cockcroft, has recently pointed out, much of the scientific work carried out at the Establishment is published in the regular scientific periodicals; indeed, more than a hundred articles have appeared in the past year. Nevertheless, the general availability of these scientific reports is most welcome, since they not only indicate the wide range of problems dealt with at Harwell but also show that atomic research, in spite of the fact that some of its results must, because of their military importance, remain secret, makes a very large contribution to the advance of the physical and medical sciences. The reports are not limited to nuclear processes, but deal with a variety of subjects, including vacuum appliances and techniques, electronic instruments, temperature measurement and statistical and mathematical methods. The March issue of the Atomic Scientists News $(1,177 ; 1952)$ prints a list of the reports.

\section{Society of General Microbiology}

At the annual general meeting of the Society for General Microbiology, held at Oxford on April 15, the following officers were appointed for 1952-53 : President, Mr. H. J. Bunker ; Honorary Secretaries, Dr. J. G. Davis (general) and Dr. E. F. Gale (meetings) ; Honorary Treasurer, Dr. R. Lovell ; Honorary Editors, Prof. B. C. J. G. Knight and Mr. A. F. B. Standfast. A very successful symposium on "The Nature of Virus Multiplication" was held during April 16-17 and attended by more than three hundred microbiologists; the papers and discussion in this symposium will be published in book form under the editorship of Sir Paul Fildes and Dr. W. E. van Heyningen. Information about the Society can be obtained from Dr. J. G. Davis, 52 London Road, Reading, Berks.

\section{Histochemical Society}

Aт a meeting of the Histochemical Society in New York on April 7-8 the following officers and councillors were elected: President, Dr. Stuart Mudd (University of Pennsylvania); Vice-President, Dr. J. Walter Wilson (Brown University); Secretary, Dr. Ralph D. Lillie (National Institutes of Health, Bethesda); Treasurer, Dr. Edward W. Dempsey (Washington University); Councillors for four years, Dr. Arnold Lazarow (Western Reserve University) and Dr. Albert H. Coons (Harvard University). At the meeting, sixty-two new members joined the Society, and Prof. R. R. Bensley (University of Chicago) and Dr. L. Lison (University of Brussels) were elected to honorary membership.

\section{Society for Endocrinology : Officers and Committee}

OFFICERS and the committee of the Society for Endocrinology have been elected as follows: Chairman, Dr. S. J. Folley ; Honorary Secretaries, Prof. C. H. Gray and Prof. N. F. Maclagan; Honorary Treasurer, Dr. F. L. Warren; Editor of the Society's Proceedings, Prof. S. Zuckerman; Ordinary Members of Committee, Dr. E. C. Amoroso, Dr. G. W. Harris, Dr. C. J. O. R. Morris and Dr. S. L. Simpson. Communications should be sent to Prof. C. H. Gray at the Department of Chemical Pathology, King's College Hospital, Denmark Hill, London, S.E.5.

\section{Second International Congress of Biochemistry, Paris}

THE Second International Congress of Biochemistry will be held in the Sorbonne, Paris, during July 21-27, under the presidency of Prof. R. Fabre, with Prof. G. Bertrand as president of honour. The programme has been arranged in seven sessions as follows: biochemistry of hæmatopoiesis; biogenesis of proteins; tricarboxylic acid cycle; protein hormones and hormones derived from proteins; bacterial metabolism; mode of action of the antibiotics; and biochemistry of steroids. The following general lectures will be given to the Congress: Prof. J. N. Davidson, nucleoproteins and tissue growth; Prof K. Linderström-Lang, proteins and enzymes; and Prof. S. Ochoa, carbon dioxide fixation in animals and plants. Further details can be obtained from the general secretary of the Congress, Prof. J.-E. Courtois, 4 Avenue de l'Observatoire, Paris, 6e.

\section{Textile Institute: Annual Conference}

THE annual conference of the Textile Institute will be held in the Assembly Rooms, George Street, 